\title{
Ionophore A23187 Induced Reductions in Toad Urinary Bladder Epithelial Cell Oxidative Phosphorylation and Viability
}

\author{
Implications for A23187 Related Declines in Epithelial Active Transport
}

\author{
H. David Humes and Joel M. Weinberg \\ Department of Internal Medicine, University of Michigan, Ann Arbor, Michigan 48109, USA
}

\begin{abstract}
The divalent cation ionophore A23187 increased oxygen consumption by isolated epithelial cells from toad urinary bladder, an increase similar to that seen with 2,4-dinitrophenol, a classic uncoupler of mitochondrial oxidative phosphorylation. This respiratory stimulation was not seen in calcium-free incubation media. That this A23187 induced rise in cell oxygen consumption was due to a primary uncoupling action on mitochondrial oxidative phosphorylation rather than secondary to stimulation of cellular transport processes and mediated via increased cellular ADP levels was suggested by the ability of A23187 to release the inhibition of cellular respiration by oligomycin, an inhibitor of the mitochondrial proton ATPase which blocks the stimulation of mitochondrial respiration by ADP. Since active transepithelial ion transport and cellular energy production are closely linked processes, the uncoupling action of A23187 in the presence of extracellular calcium is sufficient to account for an acute decline in active ion transport across epithelia without invoking other calcium-mediated processes. Furthermore, isolated epithelial cells exposed to A23187 for $90 \mathrm{~min}$ had greater than $50 \%$ loss of viability, as measured by failure of Trypan blue exclusion. The subacute A23187 induced declines in transepithelial transport, therefore, may be secondary to its non-specific effects on cell viability.
\end{abstract}

Key words: Calcium ionophore - A23187 - Epithelial transport - Toad urinary bladder - Oxidative phosphorylation - Oxygen consumption - Cell viability.

\section{Introduction}

Emerging evidence in a variety of epithelia suggests that the cytosolic calcium ion $\left(\mathrm{Ca}^{2+}\right)$ concentration is a critical regulator of transepithelial active ion transport

Send offprint requests to: $\mathrm{H}$. D. Humes at the above address
[17]. In this regard, a number of studies have demonstrated that increases in intracellular $\mathrm{Ca}^{2+}$ levels appear to inhibit active ion transport $[1,20]$. Maneuvers designed to raise cy tosolic $\mathrm{Ca}^{2+}$ activity, however, have usually depended on the use of divalent cation ionophores, in general [17], and A23187, in particular $[1,20]$. Of note, $\mathrm{Ca}^{2+}$ and $\mathrm{A} 23187$ are potent uncouplers of mitochondrial oxidative phosphorylation $[2,11]$. Since active ion transport and cellular energy production are tightly linked processes [19], the uncoupling action of these compounds may be sufficient to account for their inhibitory influence on active transepithelial ion transport without invoking other calcium related processes. To determine the effect of A23187 and $\mathrm{Ca}^{2+}$ on energy production in transporting epithelia, the effect of these agents on oxygen consumption by isolated epithelial cells from toad urinary bladder was studied. Furthermore, since cellular calcium overload secondary to alterations in plasma membrane calcium permeability appears to be an important final common pathway leading to cell death [14] and prolonged cell exposure to A23187 and $\mathrm{Ca}^{2+}$ has been shown to be detrimental to cell viability in other tissues [14], the subacute effect of A23187 on toad bladder epithelial cell viability was also assessed.

\section{Materials and Methods}

Cell Isolation. Toads (Bufo marinus) were obtained from National Reagents (Bridgeport, CT, USA). Amphibian Ringer's solution, containing $113 \mathrm{mM} \mathrm{NaCl}, 2.5 \mathrm{mM} \mathrm{KCl}, 2.5 \mathrm{mM} \mathrm{NaHCO}, 2 \mathrm{mM}$ $\mathrm{CaCl}_{2}, 5 \mathrm{mM}$ Tris $\mathrm{HCl}(\mathrm{pH} 8.0)$, and $5 \mathrm{mM}$ glucose was used in all experiments. Epithelial cells were collected by scraping with a glass slide the mucosal surface of hemibladders twice washed in no added calcium Ringer's and incubated for $45 \mathrm{~min}$ in well aerated calciumfree Ringer's containing $1 \mathrm{mM}$ ethyleneglycol-bis-( $\beta$-aminoethyl ether) $N, N^{\prime}$-tetraacetic acid (EGTA). The isolated cells were suspended in no added calcium Ringer's solution and the cell pellet was obtained by centrifugation at $500 \mathrm{~g}$ for $10 \mathrm{~min}$. The cells were resuspended in appropriate Ringer's solution and kept at $4^{\circ} \mathrm{C}$ for the remainder of the experiment. An average hemibladder yielded approximately $2-4 \mathrm{mg}$ protein of epithelial cells. 
Oxygen Consumption. Oxy gen consumption of isolated epithelial cells was measured polarographically [4] at $25^{\circ} \mathrm{C}$ employing a Clark electrode in a closed calibrated $1.4 \mathrm{ml}$ vessel with stirring bar and thermostatistically controlled bath (Model K-IC, Gilson Medical Electronics, Inc., Middleton, WI, USA). Each experiment was started by adding cells, containing between 1 and $3 \mathrm{mg}$ of cellular protein, to the oxygraph vessel. After obtaining a basal rate of oxygen consumption for 2-3 min, the initial change in cell respiration in response to the various experimental agents was measured.

Cell Viability. Cells were isolated as above and suspended in amphibian Ringer's solution to give a final cell concentration of approximately $2 \times 10^{6} \mathrm{cells} / \mathrm{ml}$. Cells were treated with sodium cyanide (10 mM), A23187 ( 2 and 10 nmoles/mg cell protein), and sham solution for $90 \mathrm{~min}$ at $22^{\circ} \mathrm{C}$. Cell viability was assesed by Trypan blue exclusion, a well established assay for viability $[5,14]$. Trypan blue $(2.0 \%$ in $0.45 \% \mathrm{NaCl})$ was added directly to cell suspensions to give a final concentration of $0.67 \%$. Within $10 \mathrm{~min}$ the number of cells which did and did not exclude the dye was counted in a hemocytometer in duplicate. Trypan blue exclusion, and thus cell viability, is expressed as the percentage of unstained cells to total stained and unstained cells. A yield of $(2-4) \times 10^{6}$ cells per hemibladder with $\sim 90 \%$ viability was obtained.

Reagents. A23127 was a generous gift from Dr. Robert Hamil, Eli Lilly Company (Indianapolis, IN, USA). All other reagents were obtained from Sigma Chemical Company (St. Louis, MO, USA). A23187, 2,4 dinitrophenol (DNP) and oligomycin were dissolved in absolute ethanol in quantities to deliver the required concentration in $10 \mu \mathrm{l}$ aliquots. In all instances, absolute ethanol was used as the sham solution.

Statistical Methods. Student paired $t$-tests were used for statistical analysis. Significance is defined as $P<0.05$ two-tailed.

\section{Results \\ Effects of $\mathrm{A} 23187$ and $\mathrm{Ca}^{2+}$ on Epithelial Cell Oxygen Consumption}

A23187, 80 nmoles/mg protein, immediately increased oxygen consumption by epithelial cell suspensions from a basal level of $7.9 \pm 1.0-13.8 \pm 1.6$ natom equivalents oxygen $/ \mathrm{min} / \mathrm{mg}$ protein $(n=6, P<0.001)$, an increase similar to that seen with $10^{-4} \mathrm{M}$ DNP (Table 1). The actual record of a typical experiment is illustrated in the left hand panel of Fig. 1. As little as 4 nmoles/mg protein of $\mathrm{A} 23187$ produced a detectable stimulation of oxygen consumption from a mean baseline value of $8.7 \pm 1.1-14.3 \pm 1.6$ natom equivalents oxygen $/ \mathrm{min} / \mathrm{mg}$ protein. The presence of $\mathrm{Ca}^{2+}$ in the incubation medium was necessary for this response since no stimulation of respiration by A23187 was observed in either a no added calcium incubation or a calcium-free medium containing $1 \mathrm{mM}$ EGTA. Of note, addition of absolute ethanol, sham solution, had no effect on cell respiration.

Furthermore, treatment of the cell suspensions with oligomycin lowered control oxygen consumption over a $5 \mathrm{~min}$ period from $8.1 \pm 0.9-3.0 \pm 0.2$ natom equivalents oxygen $/ \mathrm{min} / \mathrm{mg}$ protein $(n=18, P<0.001)$. Subsequent addition of A23187 ( $80 \mathrm{nmoles} / \mathrm{mg}$ protein) increased oxygen consumption to a significantly
Table 1. Effects of A23187 and DNP on oxygen consumption by isolated toad bladder epithelial cells

\begin{tabular}{|c|c|c|c|}
\hline \multirow[t]{2}{*}{ Agent } & \multirow[t]{2}{*}{$n$} & \multicolumn{2}{|c|}{$\begin{array}{l}\text { Oxygen consumption } \\
\text { (natom equivalents } \\
\text { oxygen } / \mathrm{min} / \mathrm{mg} \text { protein) }\end{array}$} \\
\hline & & Control & Experimental \\
\hline Sham & 8 & $8.2 \pm 1.2$ & $8.0 \pm 1.0$ \\
\hline $\begin{array}{l}\text { A } 23187 \\
\quad(80 \text { nmoles } / \mathrm{mg} \text { protein })\end{array}$ & 7 & $7.9 \pm 1.0$ & $13.8 \pm 1.6^{*}$ \\
\hline $\begin{array}{l}\text { A23187 } \\
\quad(4 \text { nmoles } / \text { mg protein })\end{array}$ & 6 & $8.7 \pm 1.1$ & $14.3 \pm 1.6^{*}$ \\
\hline DNP $\left(10^{-4} \mathrm{M}\right)$ & 6 & $7.6 \pm 1.2$ & $13.1 \pm 2.5^{*}$ \\
\hline
\end{tabular}

Data expressed as mean $\pm \mathrm{SE}$

$* P<0.001$ compared to control

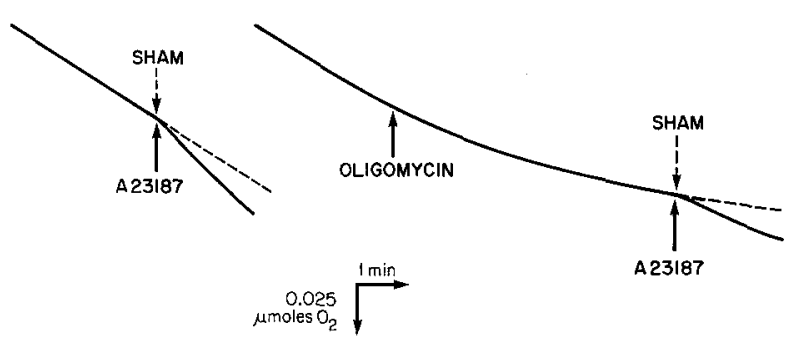

Fig. 1. Typical tracings of the respiratory responses of isolated epithelial cell suspensions from toad urinary bladder. Epithelial cells ( $3 \mathrm{mg}$ protein) were incubated in amphibian Ringer's containing $2 \mathrm{mM} \mathrm{CaCl}_{2}$. At the indicated times, additions were made to give final concentrations in the incubation medium of: A23187 ( $80 \mathrm{nmoles} / \mathrm{mg}$ protein), oligomycin $(20 \mu \mathrm{g} / \mathrm{ml})$. Sham solution was $10 \mu 1$ absolute ethanol, the solvent for A23187 and oligomycin

$(P<0.01)$ higher mean value of $7.8 \pm 0.5$ natom equivalents oxygen $/ \mathrm{min} / \mathrm{mg}$ protein. The actual record of a typical experiment is illustrated in the right hand panel of Fig. 1. An effect similar to that of A23197 was obtained by adding $10^{-4} \mathrm{M}$ DNP in the presence of oligomycin (Table 2).

\section{Effects of $\mathrm{A} 23187$ and $\mathrm{Ca}^{2+}$ on Epithelial Cell Viability}

Cells incubated in the presence of A23187 (10 nmoles/mg protein) for $90 \mathrm{~min}$ had greater than $50 \%$ loss of viability, as measured by failure of Trypan blue exclusion (Table 3 ). This rate was demonstrably greater than time and sham controls and was similar to that observed with cyanide $(10 \mathrm{mM})$. A lower dosage of A23187 ( 2 nmoles/mg protein) had a less pronounced, but still significantly greater than control, effect on cell viability. Absolute ethanol, sham solution, did not decrease cell viability.

\section{Discussion}

Recent interest has focused upon the role of cytosolic $\mathrm{Ca}^{2+}$ activity in the regulation of transepithelial active 
Table 2. Effects of A23187 and DNP in the presence of oligomycin on oxygen consumption by isolated toad bladder epithelial cells

\begin{tabular}{lll}
\hline Agent & $n$ & $\begin{array}{l}\text { Oxygen consumption } \\
\text { (natom equivalents } \\
\text { oxygen } / \text { min } / \mathrm{mg} \text { protein) }\end{array}$ \\
\hline $\begin{array}{l}\text { Control } \\
\text { Oligomycin }(20 \mu \mathrm{g} / \mathrm{ml})\end{array}$ & 18 & $8.1 \pm 0.9$ \\
$\begin{array}{l}\text { Oligomycin }(20 \mu \mathrm{g} / \mathrm{ml}) \\
\quad+\text { Sham }\end{array}$ & 6 & $3.1 \pm 0.2^{*}$ \\
$\begin{array}{l}\text { Oligomycin }(20 \mu \mathrm{g} / \mathrm{ml}) \\
\quad+\text { A23187 } \\
\quad(80 \text { nmoles } / \mathrm{mg} \mathrm{protein)}\end{array}$ & 6 & $7.8 \pm 0.5^{* * *}$ \\
$\begin{array}{l}\text { Oligomycin }(20 \mu \mathrm{g} / \mathrm{ml}) \\
\quad+\text { DNP }\left(10^{-4} \mathrm{M}\right)\end{array}$ & 6 & $8.5 \pm 1.2^{* *}$ \\
\hline
\end{tabular}

Data expressed as mean $\pm \mathrm{SE}$

* $P<0.001$ compared to control

** $P<0.01$ compared to oligomycin + sham

Table 3. Effect of cyanide and A23187 on toad bladder epithelial cell viability

\begin{tabular}{llll}
\hline Agent & $n$ & \multicolumn{2}{c}{ Viability (\%) } \\
\cline { 2 - 4 } & & Control & Experimental \\
\hline Sham & 6 & $89 \pm 1$ & $88 \pm 1$ \\
$\begin{array}{l}\text { Cyanide }(10 \mathrm{mM}) \\
\text { A23187 }\end{array}$ & 6 & $87 \pm 2$ & $44 \pm 2^{*}$ \\
$\quad(10$ nmoles/mg protein) & 6 & $88 \pm 2$ & $48 \pm 2^{*}$ \\
$\begin{array}{c}\text { A23187 } \quad(2 \text { nmoles/mg protein }) \\
\quad 4\end{array}$ & 4 & $87 \pm 2$ & $68 \pm 2^{* *}$ \\
\hline
\end{tabular}

Data expressed as mean $\pm \mathrm{SE}$

* $P<0.001$ compared to control

** $P<0.01$ compared to control

ion transport. To shed light on this problem a variety of agents which alter calcium flux across membranes have been utilized in various transporting epithelia [7]. Divalent cation ionophores, in general, and the calcium ionophore A23187, in particular, have been commonly used agents to increase calcium flux across biological membranes and, thereby, presumably, to increase the cytosolic $\mathrm{Ca}^{2+}$ concentration $[1,17,20]$. In this regard, A23187 has been shown to inhibit active sodium transport in toad urinary bladder [20] and active hydrogen ion transport in turtle urinary bladder [1]. These results have led to the suggestion that an increase in cystolic $\mathrm{Ca}^{2+}$ activity either inhibits directly intrinsic ion pump activity or alters luminal membrane ion permeability [17].

In light of the experiments reported herein, however, an additional mechanism for this A23187 in- duced decline in active transepithelial ion transport must be considered: the effect of $\mathrm{A} 23187$ and $\mathrm{Ca}^{2+}$ on mitochondrial oxidative phosphorylation and, therefore, on cellular energy production. Abundant evidence exists for a close linkage between active transepithelial transport and epithelial cell energy production [19]. In fact, DNP, a classic uncoupler of mitochondrial oxidative phosphorylation, leads to a rapid and immediate decline in transepithelial active transport in anuran membranes [3]. In the present experiments, both DNP and A23187 significantly increased oxygen consumption of epithelial cell suspensions. The A23187 induced rise in cell respiration is consistent with an uncoupling action of A23187 on mitochondrial oxidative phosphorylation, an effect also recently reported in bovine spermatozoa [2].

In isolated mitochondria, the uncoupling action of A23187, and, therefore, the stimulation of mitochondrial respiration, is due to a cyclical calcium flux across the mitochondrial inner membrane [13]. In whole cells, the A23187 induced rise in respiration may be due to primary effects on either the plasma membrane or the mitochondrial membrane. A23187 mediated alterations in plasma membrane calcium permeability may result in a persistent flux of $\mathrm{Ca}^{2+}$ into the cytosol and continuous uptake of $\mathrm{Ca}^{2+}$ by mitochondria; or A23187 mediated alterations in inner mitochondrial membrane calcium permeability may result in repetitive recycling of intracellular $\mathrm{Ca}^{2+}$ as described above. In either case, since mitochondrial calcium transport occurs as an alternative to, and at the expense of, ATP synthesis and dissipates the electrochemical proton gradient across the inner mitochondrial membrane, elevated respiratory rates and uncoupling of oxidative phosphorylation occur. The requirement for extracellular $\mathrm{Ca}^{2+}$ to increase cellular respiration in these studies suggest that A23187 and endogenous cell calcium alone are not sufficient to activate these processes.

Since mitochondrial respiration accounts almost entirely for epithelial cell oxygen consumption, the A23187 related increase in epithelial cell oxygen consumption is mitochondrial in origin. This increase in mitochondrial oxygen consumption, however, may not be from an uncoupling action of $\mathrm{Ca}^{2+}$ and $\mathrm{A} 23187$ but from a requirement for increased cellular energy production to fuel, for example, calcium pumps on the plasma membrane to maintain low levels of cytosolic $\mathrm{Ca}^{2+}$ threatened by A23187 induced alterations in membrane calcium permeability. To differentiate between these possibilities, the respiratory response of epithelial cells to A23187 in the presence of oligomycin was measured. Oligomycin inhibits the mitochondrial $\mathrm{F}_{1} \mathrm{~F}_{\mathrm{o}}$ ATPase and prevents the utilization of the electrochemical proton gradient across the mitochon- 
drial inner membrane to form ATP from ADP and inorganic phosphate [7,12], and thereby the ability of ADP to stimulate mitochondrial respiration. It is effective in both isolated mitochondria and intact cell preparations $[3,8,18]$. In the present studies, oligomycin demonstrably lowered oxygen consumption of epithelial cell suspensions to $30 \%$ of basal levels. The observation that A23187, like DNP, more than doubled this lower rate of cell respiration induced by oligomycin indicates that the stimulation of cellular oxygen consumption by A23187 does not arise from increased mitochondrial substrate oxidation in response to higher intracellular ADP levels, but is, rather, due to an uncoupling effect [9]. Consistent with this finding are recent observations that A23187 dramatically lowers ATP levels in a variety of tissues $[6,16]$.

Experiments examining the effects of A23187 on active transport processes in epithelia have frequently used prolonged incubation periods $[1,20]$. In view of the acute deleterious effects of A23187 on mitochondrial oxidative phosphorylation [13] and the subacute detrimental effects of cellular calcium overload on cell viability [14], the inhibition of active transport after prolonged epithelial cell exposure may also be due to non-specific toxic effects on cell function. The present studies demonstrate that more than $50 \%$ of isolated epithelial cells exposed to A23187 (10 nmoles/mg protein) for $90 \mathrm{~min}$ were not viable as determined by Trypan blue exclusion, a well established technique for the assessment of cell viability $[5,14]$. This decline in viability was quantitatively similar to that seen with $10 \mathrm{mM}$ cyanide and was significantly greater than time and sham controls. This toxic effect of A23187 appears to be dose related in that a lower dose of A23187 had an appreciably lesser effect on cell viability.

In conclusion, the inhibitory effects of A23187 on active transepithelial ion transport may be explained acutely by its uncoupling action on mitochondrial oxidative phosphorylation in the presence of extracellular calcium and subacutely by its non-specific toxic effects on cell viability. Future interpretation of A23187 related inhibitory effects on energy dependent cellular processes must consider the possible action of this agent on cellular energy production. Furthermore, because of the lipophilic nature of $\mathrm{A} 23187$, it will have demonstrable effects not only on plasma membranes, but subcellular organellar membranes, as well. In this regard, the ultimate influence of A23187 on cellular calcium levels and thus on cellular function will be a complex interplay of at least its partition coefficients in various biological membranes, its concentration, and the concentration of ionized calcium in the incubation medium. Acknowledgement of these factors will result in the careful use of this already valuable agent to better understand the role of $\mathrm{Ca}^{2+}$ in cellular processes.

\section{References}

1 Arruda JAL (1979) Calcium inhibits urinary acidification : Effect of ionophore A23187 on the turtle bladder. Pflügers Arch $381: 107-111$

2 Babcock DF, First NL, Lardy HA (1976) Action of ionophore A23187 at the cellular level. J Biol Chem 251:3881-3886

3 Bricker NS, Klahr S (1966) Effects of dinitrophenol and oligomycin on the coupling between anaerobic metabolism and anaerobic sodium transport by the isolated turtle bladder. J Gen Physiol 49: 483-499

4 Estabrook RW (1967) Mitochondrial respiratory control and the polarographic measurement of ADP: $O$ ratios. Methods Enzymol 10:41-47

5 Girardi AJ, McMichael H, Jr, Henle W (1956) The use of HeLa cells in suspension for the quantitative study of virus propagation. Virology 2:532-544

6 Friedmann N, Divakaran P, Kirkland J, Kimura S, Wood J (1979) Effects of the calcium ionophore A23187 on liver metabolism. J Pharmacol Exp Ther 211:127-132

7 Kagawa Y, Racker R (1966) Partial resolution of the enzymes catalyzing oxidative phosphorylation. Properties of a factor conferring oligomycin sensitivity on mitochondrial adenosine triphosphatase. J Biol Chem $241: 2461-2466$

8 Kováč L, Hrušovská E, Šmigáň P (1970) Oxidative phosphorylation in yeast. VII. Inhibition of oxidative phosphorylation and of respiratory enzyme synthesis by oligomycin in intact cells. Biochim Biophys Acta 205:520-523

9 Lardy HA, Connelly JL, Johnson D (1964) Antibiotics as tools for metabolic studies. II. Inhibition of phosphoryl transfer in mitochondria by oligomycin and aurovertin. Biochemistry 12:1961-1968

10 Lardy HA, Johnson D, McMurray WC (1958) Antibiotics as tools for metabolic studies. I. A survey of toxic antibiotics in the respiratory, phosphorylative, and glycolytic systems. Arch Biochem Biophys 78:587-597

11 Lehninger AL, Raynafarje B, Vercesi A, Tew WP (1978) Transport and accumulation of calcium in mitochondria. Ann NY Acad Sci 307:160-176

12 Mitchell P (1979) Keilin's respiratory chain concept and its chemiosmotic consequnces. Science 206:1148-1159

13 Reed PW, Lardy HA (1972) A23187: a divalent cation ionophore. J Biol Chem 247:6970-6977

14 Schanne FAX, Kane AB, Young EE, Farber JL (1979) Calcium dependence of toxic cell death: a final common pathway. Science 206: $700-702$

15 Selwyn MJ, Dawson AP, Dunnett SJ (1970) Calcium transport in mitochondria. FEBS Lett 10:1-5

16 Tamarit-Rodriguez E, Hellman B, Sehlin J (1977) Metabolic characteristics of pancreatic $\beta$-cells exposed to calciumtransporting ionophore. Biochim Biophys Acta 496:167-174

17 Taylor A, Windhager EE (1979) Possible role of cytosolic calcium ånd $\mathrm{Na}-\mathrm{Ca}$ exchange in regulation of transepithelial sodium transport. Am J Physiol 236: F505-F512

18 Van Rossum GDV (1976) The effects of oligomycin on energy metabolism and cation transport in slices of rat liver. Biochim Biophys Acta 423:111-121

19 Weiner MW, Maffly RH (1978) The provision of cellular metabolic energy for active ion transport. In: Andreoli TE, Hoffman JF, Fanestil DD (eds) Physiology of membrane disorders. Plenum Publishing Corp., New York, p 287

20 Wiesmann W, Sinha S, Klahr S (1977) Effects of ionophore A23187 on baseline and vasopressin stimulated sodium transport in the toad bladder. J Clin Invest 59: $418-425$

Received June 18 / Accepted September 22, 1980 